\title{
Academic Conflicts in Higher Education Institutions
}

\author{
Kseanela Sotirofski \\ University "A. Moisi", Faculty of Education \\ nelasotiri@yahoo.com
}

\section{Doi:10.5901/mjss.2014.v5n16p716}

\begin{abstract}
The main aim of this study is to explore the prevalence of academic conflicts in public universities in Albania. The focus of the study is on the ideologies of academic work in regard to the purpose of higher education and higher education law requirements for their work load. The conception of academic identity conflict is predicated on the conflicting professional ideological beliefs needed to realize functions of public universities. The milestones on which the study is focused are the identity problems as a result of pressure to compose the institution, the contradictory values and beliefs and the position in the hierarchy of the institution. A survey send electronically is used to collect data for the purpose of the study. A discourse voiced by academics in this study could help connect and guide the managerial and academic arms of the university: educational principles should stand above market principles and business interests should not be allowed to determine primarily what knowledge needs to be kept, transferred or intellectually valued in higher education.
\end{abstract}

Keywords: Academic identity, public university, work ideology

\section{Introduction}

As the main mission of higher education in Albania is defined as the institution which raises the new generation to be ready for the job market, the public universities in Albania are trying to redefine themselves as organizations which are more commercial, business oriented and the academicians work also market oriented too. In the new corporate style university, managerialism and its associated ideologies have transformed the nature of public universities, "making them into producers of commodities that consumers (students) may choose to demand depending on their competing preferences and the institution's perceived brand image" (Winter, 2009). So, the purposes and achievements are replaced by a symbolic of the values of business and industry with students, knowledge, research and teaching/learning being portrayed as "products of the university" (Saunston \& Morrish, 2011).

Identity conflicts are defined as cognitive states of separation that is caused by from academic work required by the university that embodies corporate beliefs that conflict with a valued professional self-identity (Winter, 2009). As a state of separation, identity conflicts signify a different conception of the academic self to that prescribed by the university and this state affects academic motivation, job satisfaction, commitment, and effectiveness (Churchman, 2006). Identities are pluralistic in public universities and they change by the aim of the academic work and higher education system (Henkel, 2005). In this environment, some academics will line up themselves with the university as an enterprise or divide their academic work from the demands of an enterprise. The main aim of this study is to break through the academic identity sorts by taking the views of the academicians for a market oriented of professional conception of academic work in special and higher education in general.

Essentially, the identity perspective is conciliated by Hussey and Smith (2010) in their critique of the higher education system in the UK: "As language changes, so does thinking, and as thinking changes so does action and with it the whole experience of [higher] education" (p. 22).

\section{What is Work Ideology?}

Work ideology is the processes of academic identity alignment precipitated by the "emotional, action-oriented beliefs" individual academics use in realizing their work and the higher education sector more broadly (Trice, 1993). In the cognitive view of identity is the notion that emotional beliefs act as a foundation and guide to an individual's behavior by managing styles of thought and helping people rationalize their worlds (Beyer, Dunbar, \& Meyer, 1988). In a moral sense, work ideologies shape the rights and wrongs of academic behavior by turning moral meanings to concrete actions (Blasi, 1984). Economic-consumer conceptions of higher education and academic work trigger competing identity claims as to 
what is central to academic work (Billot, 2010). In the expression of these identity claims, individuals and occupational groups may experience various degrees of identity conflict.

Work ideologies may also serve the future careers of academics in different positions in the hierarchy of the university (Winter, 2009). The forms of academic identity we argue are connected to work ideologies that make together or separate academics in their current work roles in the university.

\section{Professional and Managerial ideology at academic work}

A managerial work ideology is based at the legitimization of market-based higher education (Deem \& Brehony, 2005). Its function is to make the education more market oriented and business competitive, to be a business incubator and to treat students like consumers. According to this ideology, consumers' preferences are the key of higher education funds (Furedi, 2011).

A professional work ideology is based on economic and social welfare of all members of society. The most import issue to a professional work ideology is the occupational principle academics have the required knowledge, training, and skills to teach and research in their chosen discipline areas without management interference (Churchman \& King, 2009).

\section{Methodology}

The sample of this study is a public Albanian university. A survey sent electronically was used to examine the importance of professional and managerial academic ideologies in the university.

The survey was a semi structured one. Some questions related to gather data about the academicians beliefs regarding to the overall aim of higher education, the social and academic roles.

In order to connect to identity, work ideology statements were framed as paired statements reflecting the pressure between managerial and professional issues regarding to how higher education is organized (Winter, 2009) and the survey participants were presented with two paired survey items and asked to choose one particular work ideology over the other. Also, an open-ended comments box was included after each survey question.

\section{Sample}

74 academicians have responded to the survey out of 126 ones. They were drawn by universities all faculties. Respondents were grouped in the following discipline areas: social sciences (36\%), information technology (14\%), health science (13\%), economy (27\%), and jurisprudence (10\%). Most respondents were female (70\%) and average age of respondents was 36 years.

\section{Data analysis}

Analysis and coding of data was based on the anecdotes used by respondents to express their beliefs about the purpose of higher education and academic work (Phillips \& Hardy, 2002). Tables provided data related to the profile of respondents by showing how work ideologies are related to the beliefs.

\section{Discussion of the Results}

Table 1 shows the academicians responses to professional work ideology. A majority of academicians (78\%) said that higher education should be promoted on the basis of educational need and academic standards principles'. Over $84 \%$ of academicians said that the HE institutions should be learning places where the aim must be student teaching and learning. And just $22 \%$ of respondents valued the HE as a market valued. So, the professional goals goes over the managerial goals. 
Table 1: Academicians frequency responses to work ideology

\begin{tabular}{|c|l|c|}
\hline No. & Work ideology & Frequencies \\
\hline 1 & Market based principles & 22 \\
\hline 2 & Academic standards based principles & 78 \\
\hline 3 & Students as consumers & 36 \\
\hline 4 & Students as learners by structured curricula & 64 \\
\hline 5 & Funds by scholarships & 47 \\
\hline 6 & Funds by industry linkages & 53 \\
\hline 7 & Management by business stakeholders & 20 \\
\hline 8 & Management by academicians & 80 \\
\hline
\end{tabular}

As clearly observed by table 1 , the academicians give the emphasis to the academic standarts, academic and standardized learning and management of the university by academicians.

Table 2: Professional work ideology

\begin{tabular}{|l|l|}
\hline Professional work ideology statements & Beliefs \\
\hline Education is a public-good that the market & Education isn't a product that can be bought \\
\cline { 2 - 2 } does not value very well & Education based on market limits the academic learning and is limited \\
\cline { 2 - 2 } & Market based education trains, academic education trains and educates. \\
\cline { 2 - 2 } & Education is related to social needs and regulations, not just factories needs. \\
\cline { 2 - 2 } & Higher education purpose must be inventing, not reproducing as market needs. \\
\hline
\end{tabular}

\section{Discussion of the Results}

Identity conflict is related to the social purposes of a university and the risk that may come from the market view to the academic-student teaching-learning relationship. Referring to identity conflict as an ideological response to a new mission of higher education shows that identities are in the process of being changed and are subject to change as the relations, practices and discourses that individuals change". In order for academics to percept new identities, ideas and practices, leaders in higher education should integrate the principles and beliefs of academics across the disciplines.

\section{References}

Beyer, J., Dunbar, R.L., \& Meyer, A.D. (1988). Comment: The concept of ideology in organizational analysis. Academy of Management Review, 13, 483-489.

Billot, J. (2010). The imagined and the real: Identifying the tensions for academic identity. Higher Education Research \& Development, 29(6), 709-721.

Blasi, A. (1984). Moral identity: Its role in moral functioning. In W. Kurtines \& J. Gewirtz (Eds.), Morality, moral

Churchman, D. (2006). Institutional commitments, individual compromises: Identity-related responses to compromise in an Australian university. Journal of Higher Education Policy and Management, 28(1), 3-15.

Churchman, D., \& King, S. (2009). Academic practice in transition: Hidden stories of academic identities. Teaching in Higher Education, 14(5), 507-516.

Deem, R., Hillyard, S., \& Reed, M. (2008). Knowledge, higher education, and the new managerialism: The changing management of UK universities. Oxford: Oxford University Press.

Furedi, F. (2011). Introduction to the marketisation of higher education and the student as consumer. In M. Molesworth, R. Scullion, \& E. Nixon (Eds.), The marketisation of higher education and the student as consumer (pp. 1-7). London and New York: Routledge.

Henkel, M. (2005). Academic identity and autonomy in a changing policy environment. Higher Education, 49, 155-176.

Hussey, T., \& Smith, P. (2010). The trouble with higher education: A critical examination of our universities. New York and London: Routledge.

Saunston, H., \& Morrish, L. (2011). Vision, values and international excellence: the 'products' that university mission statements sell to students. In M. Molesworth, R. Scullion, \& E. Nixon (Eds.), The marketisation of higher education and the student as consumer (pp. 73-85). London and New York: Routledge.

Trice, H.M. (1993). Occupational subcultures in the workplace. Ithaca, NY: ILR Press.

Weiss, R.M., \& Miller, L.E. (1987). The concept of ideology in organizational analysis: The sociology of knowledge or the social psychology of beliefs? Academy of Management Review, 12(1), 104-116.

Winter, R.P. (2009). Academic manager or managed academic? Academic identity schisms in higher education. Journal of Higher Education Policy and Management, 3(2), 121-131. 